Article

\title{
Design of New $\alpha$-Conotoxins: From Computer Modeling to Synthesis of Potent Cholinergic Compounds
}

\author{
Igor E. Kasheverov *, Maxim N. Zhmak, Alexey Y. Khruschov and Victor I. Tsetlin \\ Shemyakin-Ovchinnikov Institute of Bioorganic Chemistry, Russian Academy of Sciences, \\ Miklukho-Maklaya Street, 16/10 Moscow 117997, Russia; E-Mails: zhmak@front.ru (M.N.Z.); \\ khrushh@rambler.ru (A.Y.K.); vits@mx.ibch.ru (V.I.T.) \\ * Author to whom correspondence should be addressed; E-Mail: shak_ever@yahoo.com or \\ iekash@mx.ibch.ru; Tel.: +7-495-330-7374; Fax: +7-495-335-5733.
}

Received: 1 August 2011; in revised form: 29 August 2011 / Accepted: 16 September 2011 / Published: 28 September 2011

\begin{abstract}
A series of 14 new analogs of $\alpha$-conotoxin PnIA Conus pennaceus was synthesized and tested for binding to the human $\alpha 7$ nicotinic acetylcholine receptor (nAChR) and acetylcholine-binding proteins (AChBP) Lymnaea stagnalis and Aplysia californica. Based on computer modeling and the X-ray structure of the A. californica AChBP complex with the PnIA[A10L, D14K] analog [1], single and multiple amino acid substitutions were introduced in $\alpha$-conotoxin PnIA aimed at compounds of higher affinity and selectivity. Three analogs, PnIA[L5H], PnIA[A10L, D14K] and PnIA[L5R, A10L, D14R], have high affinities for AChBPs or $\alpha 7 \mathrm{nAChR}$, as found in competition with radioiodinated $\alpha$-bungarotoxin. That is why we prepared radioiodinated derivatives of these $\alpha$-conotoxins, demonstrated their specific binding and found that among the tested synthetic analogs, most had almost 10-fold higher affinity in competition with radioactive $\alpha$-conotoxins as compared to competition with radioactive $\alpha$-bungarotoxin. Thus, radioiodinated $\alpha$-conotoxins are a more sensitive tool for checking the activity of novel $\alpha$-conotoxins and other compounds quickly dissociating from the receptor complexes.
\end{abstract}

Keywords: $\alpha$-conotoxin analogs; nicotinic acetylcholine receptors; acetylcholine-binding proteins; computer modeling; radioligand analysis 


\section{Introduction}

$\alpha$-Conotoxins are at present the most precise tools for research on nicotinic acetylcholine receptors (nAChRs), mainly due to their relatively high specificity for different $\mathrm{nAChR}$ subtypes and small size, enabling solid-phase synthesis of $\alpha$-conotoxins in large amounts (see, for example, reviews [2-5]). Involvement of distinct $\mathrm{nAChR}$ subtypes in muscle dystrophies, psychiatric, and neurodegenerative diseases [6-8] makes practical application of different cholinergic ligands crucial, including $\alpha$-conotoxins as selective markers of the respective subtypes in normal state and pathologies, as well as for designing new drugs. At present several $\alpha$-conotoxins are at different stages of preclinical tests $[9,10]$. The search for new naturally occurring $\alpha$-conotoxins and design of $\alpha$-conotoxin analogs is very active as seen from our recent review [11].

Here we tried to make new $\alpha$-conotoxin analogs of higher affinity and selectivity to a homooligomeric $\alpha 7 \mathrm{nAChR}$. This subtype is one of the best presented, especially in the brain, and appears to play an important role in Alzheimer's disease [12,13]. That is why there is a need in specific labeling and quantitative measurement of the $\alpha 7 \mathrm{nAChR}$ levels. Among $\alpha$-conotoxins, for some time such a role was ascribed to $\alpha$-conotoxin $\operatorname{ImI}[14,15]$ but later its binding to some other subtypes was registered [16,17]. Another candidate was $\alpha$-conotoxin PnIA, a $\alpha 3 \beta 2 \mathrm{nAChR}$ blocker, where a single A10L mutation shifted its specificity in favor of $\alpha 7 \mathrm{nAChR}[18,19]$. We took this peptide as a basis for designing new $\alpha$-conotoxins acting on $\alpha 7 \mathrm{nAChR}$.

To choose the amino acid substitutions, we relied upon computer modeling, based mainly on the X-ray structures of the Aplysia californica and Lymnaea stagnalis acetylcholine-binding proteins (AChBPs) and their complexes. These proteins are excellent structural models for the ligand-binding domains of all nAChR subtypes and pharmacologically are closest to $\alpha 7 \mathrm{nAChR}$ [20,21]. Since the X-ray structures of both these proteins are known, as well as the X-ray structures of Aplysia californica AChBP with three different $\alpha$-conotoxins [1,22-24], it seemed to be a good system to design $\alpha$-conotoxins with a higher selectivity. In view of this, the activity of the synthesized compounds was tested by radioligand analysis with human $\alpha 7 \mathrm{nAChR}$ in the $\mathrm{GH}_{4} \mathrm{C}_{1}$ cell line, and also with the AChBPs of the two species. Moreover, it was carried out not only in competition with the $\left[{ }^{125} \mathrm{I}\right]$ - $\alpha$-bungarotoxin $\left(\left[{ }^{125} \mathrm{I}\right]-\alpha \mathrm{Bgt}\right)$, but with the radioiodinated derivatives of our novel $\alpha$-conotoxins.

\section{Results and Discussion}

\subsection{Computer Modeling and Choice of Amino Acid Substitutions}

Computer modeling of $\alpha$-conotoxin PnIA analogs and their docking to AChBPs and nAChRs was performed using the X-ray structures of $\alpha$-conotoxins PnIA and PnIB [25,26] and the techniques and programs earlier employed with different $\alpha$-conotoxins [1,27,28] and $\alpha$-neurotoxins [29]. Models of the two AChBPs in complexes with $\alpha$-conotoxin PnIA analogs were built on the basis of the X-ray structure for Aplysia californica AChBP in complex with PnIA[A10L, D14K] [1], taking into account also the AChBP complexes with $\alpha$-conotoxins ImI and TxIA[A10L] [22-24] and with $\alpha$-cobratoxin [30]. For analysis of complexes with the $\alpha 7 \mathrm{nAChR}$, the Torpedo marmorata $\mathrm{nAChR}$ electron microscopy structure [31] was used. 
Docking allowed us to choose several substitutions in the $\alpha$-conotoxin PnIA amino acid sequence which might increase the affinity and/or selectivity. A higher selectivity might result also due to a drop in binding to other targets, yet saving the original affinity towards a certain receptor subtype. These peptides are shown in Table 1. The largest changes could be expected on introduction of charged residues into positions 5, 7 and 14 making possible strong ionic interactions between $\alpha$-conotoxins and the targets.

Table 1. Structures and molecular masses of synthesized $\alpha$-conotoxin PnIA analogs with amino acid substitutions suggested by computer modeling. Positively charged substitutions are marked in red; negatively charged - in blue; aliphatic or aromatic substitutions - in gray. PnIA[A10L], PnIA[A10L, D14K] and PnIA[L5R, A10L] were described earlier $[1,18,19,24]$. For comparison, the sequence of wild type $\alpha$-conotoxin PnIA is included.

\begin{tabular}{|c|c|c|c|}
\hline \multirow[b]{2}{*}{ Analogs of $\alpha$-conotoxin PnIA } & \multirow[b]{2}{*}{ Sequences and mutations } & \multicolumn{2}{|c|}{ Molecular masses } \\
\hline & & $\begin{array}{c}\text { Measured } \\
\left(M H^{+}\right)\end{array}$ & Calculated \\
\hline PnIA & GCCSLPPCAANNPDYC-NH $_{2}$ & - & - \\
\hline PnIA[L5H] & GCCSHPPCAANNPDYC-NH $_{2}$ & 1646.6 & 1645.6 \\
\hline PnIA[L5H, D14R] & GCCSHPPCAANNPRYC-NH $_{2}$ & 1687.3 & 1686.6 \\
\hline $\operatorname{PnIA[A10L]}$ & GCCSLPPCALNNPDYC-NH $_{2}$ & 1664.7 & 1663.7 \\
\hline PnIA[L5D, A10L] & GCCSDPPCALNNPDYC-NH $_{2}$ & 1666.7 & 1666.4 \\
\hline PnIA[L5R, A10L] & GCCSRPPCALNNPDYC-NH $_{2}$ & 1707.6 & 1706.6 \\
\hline PnIA[P7D, A10L] & GCCSLPDCALNNPDYC-NH $_{2}$ & 1682.4 & 1681.6 \\
\hline PnIA[P7R, A10L] & GCCSLPRCALNNPDYC-NH $_{2}$ & 1723.7 & 1722.9 \\
\hline PnIA[A10L, D14K] & GCCSLPPCALNNPKYC-NH & 1677.6 & 1676.8 \\
\hline PnIA[L5D, P7R, A10L] & GCCSDPRCALNNPDYC-NH $_{2}$ & 1725.7 & 1724.9 \\
\hline PnIA[L5D, P7R, A10V] & GCCSDPRCAVNNPDYC-NH $_{2}$ & 1711.6 & 1710.8 \\
\hline PnIA[L5R, P7D, A10L] & GCCSRPDCALNNPDYC-NH & 1725.4 & $\mathbf{1 7 2 4 . 6}$ \\
\hline PnIA[L5R, A10L, D14R] & GCCSRPPCALNNPRYC-NH $_{2}$ & 1748.5 & 1747.7 \\
\hline PnIA[L5D, P7R, A10L, D14R] & GCCSDPRCALNNPRYC-NH $_{2}$ & 1766.7 & 1766.0 \\
\hline PnIA[L5R, P7D, A10L, D14R] & GCCSRPDCALNNPRYC-NH & 1766.5 & 1765.7 \\
\hline PnIA[L5Y, P6R, P7R, A10L, D14R, Y15W] & GCCSYRRCALNNPRWC-NH & 1896.8 & 1895.8 \\
\hline
\end{tabular}

Interestingly, charged residues in positions 5 and 7 (D5 and R7) are present in all known $\alpha$-conotoxins of the " $4 / 3$ subgroup" ( $\alpha$-conotoxins ImI, ImII and RgIA), which have certain affinity to several nAChR subtypes including $\alpha 7 \mathrm{nAChR}[14,15,17,32]$, as well as in $\alpha$-conotoxin RgIA which is a highly specific antagonist of $\alpha 9 \alpha 10 \mathrm{nAChR}[33,34]$. Another $\alpha 9 \alpha 10 \mathrm{nAChR}$ specific ligand- $\alpha$-conotoxin Vc1.1 of the "4/7 subgroup" - also has D5 and R7 residues in its amino acid sequence [35]. On the other hand, a positively charged R5 is present in $\alpha$-conotoxin TxIA, a potent blocker of $\alpha 3 \beta 2 \mathrm{nAChR}$ and efficient ligand of Lymnaea stagnalis AChBP [24]. Histidine in position 5 can be found in the sequences of several $\alpha$-conotoxins (GIC, PeIA, OmIA) acting on different neuronal nAChRs [36-38]. The increase in the affinity due to incorporation of a positive charge into the $C$-terminal region has been demonstrated previously both for $\alpha$-conotoxins targeting the muscle-type nAChRs [27] and for $\alpha$-conotoxin PnIA interacting with neuronal nAChRs [1]. 


\subsection{Preparation of Synthetic $\alpha$-Conotoxin Analogs}

Novel $\alpha$-conotoxin analogs were prepared by the solid phase peptide synthesis, similarly to the earlier described syntheses of PnIA[A10L] and PnIA[A10L, D14K] [1]. The structures of all $\alpha$-conotoxins purified by HPLC (see some in Figure 1) were confirmed by MALDI-TOF mass-spectrometry (see Table 1).

Figure 1. HPLC re-chromatography of selected $\alpha$-conotoxin PnIA analogs.

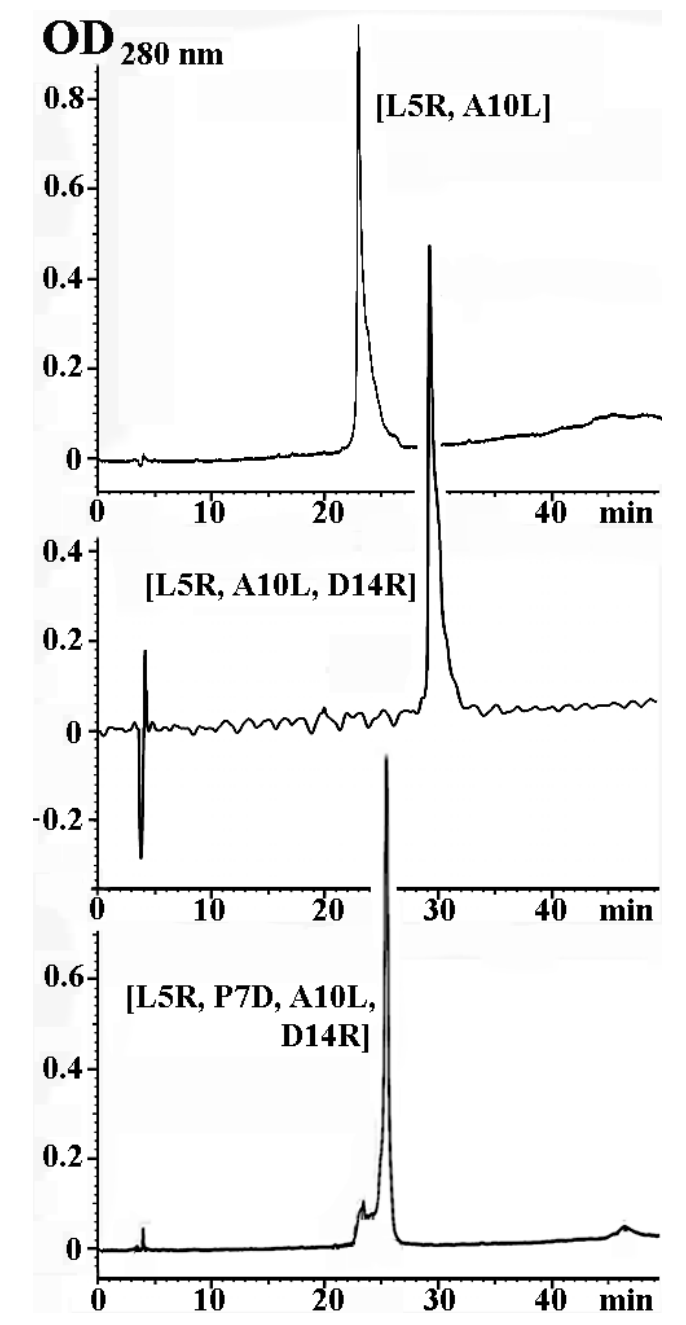

\subsection{Binding Assays with $\alpha$-Conotoxin Analogs}

Competition Radioligand Assay with $\left[{ }^{125} \mathrm{I}\right]$-Labeled $\alpha$-Bungarotoxin

All the synthesized compounds were tested in competition with $\left[{ }^{125} \mathrm{I}\right]$-labeled $\alpha$-bungarotoxin ( $\left[{ }^{125} \mathrm{I}\right]-\alpha \mathrm{Bgt}$ ) for binding to human $\alpha 7 \mathrm{nAChR}$ in the $\mathrm{GH}_{4} \mathrm{C}_{1}$ cell line and to AChBPs. The results are presented in Table 2 and are also depicted as a histogram (Figure 2). It shows a change in the analog affinity relative to one peptide chosen as a control, as a logarithm of the ratio of the two respective $\mathrm{IC}_{50}$ values. $\alpha$-Conotoxin PnIA[A10L] has been selected as a control because it has a single substitution present in the majority of other analogs. This scheme is a vivid demonstration of changes in the affinity for all targets brought about by amino acid substitutions. 
Table 2. Activity of $\alpha$-conotoxin PnIA analogs tested in competition binding assays. All listed peptides were tested in competition with $\left[{ }^{125} \mathrm{I}\right]$-labeled $\alpha$-bungarotoxin $\left(\left[{ }^{125} \mathrm{I}\right]-\alpha \mathrm{Bgt}\right)$ for binding to AChBPs and human $\alpha 7 \mathrm{nAChR}$. The presented $\mathrm{IC}_{50}$ values (in $\mathrm{nM}$ ) and Hill coefficients $\left(n_{\mathrm{H}}\right)$ were calculated using ORIGIN 7.5 with the mean \pm s.e.m. of duplicate data obtained in two or three $(n=2$ or 3$)$ independent experiments for most analogs. More data were collected for analogs PnIA[L5H], [L5R, A10L, D14R], [A10L], [A10L, D14K] and [L5R, A10L] with $n=5,5,5,6$ and 8, respectively.

\begin{tabular}{|c|c|c|c|c|c|c|}
\hline \multirow{3}{*}{$\begin{array}{l}\text { Mutations in PnIA } \\
{[\mathrm{L} 5 \mathrm{H}]} \\
\end{array}$} & \multicolumn{6}{|c|}{$\mathrm{IC}_{50}$ in $\mathrm{nM}$ and Hill slopes $\left(n_{\mathrm{H}}\right)$ in $\left[{ }^{125} \mathrm{I}\right]-\alpha$ Bgt displacement from } \\
\hline & \multicolumn{2}{|c|}{ L. stagnalis AChBP } & \multicolumn{2}{|c|}{ A. californica AChBP } & \multicolumn{2}{|c|}{ human $\alpha 7$ nAChR } \\
\hline & $220 \pm 80$ & $(0.71 \pm 0.06)$ & $3.1 \pm 0.4$ & $(1.13 \pm 0.15)$ & $26,000 \pm 1000$ & $(1.15 \pm 0.05)$ \\
\hline [L5H, D14R] & $2900 \pm 100$ & $(1.18 \pm 0.05)$ & $1400 \pm 100$ & $(1.31 \pm 0.09)$ & $21,000 \pm 1000$ & $(1.01 \pm 0.05)$ \\
\hline [A10L] & $200 \pm 40$ & $(0.89 \pm 0.13)$ & $55 \pm 12$ & $(1.18 \pm 0.24)$ & $14,000 \pm 1000$ & $(0.73 \pm 0.04)$ \\
\hline$[\mathrm{L} 5 \mathrm{D}, \mathrm{A} 10 \mathrm{~L}]$ & $35,000 \pm 3000$ & $(1.45 \pm 0.20)$ & $5200 \pm 1900$ & $(1.03 \pm 0.17)$ & $>100,000$ & $(-)$ \\
\hline$[\mathrm{L} 5 \mathrm{R}, \mathrm{A} 10 \mathrm{~L}]$ & $180 \pm 20$ & $(1.10 \pm 0.10)$ & $305 \pm 19$ & $(1.51 \pm 0.25)$ & $12,000 \pm 2000$ & $(1.03 \pm 0.11)$ \\
\hline$[\mathrm{P} 7 \mathrm{D}, \mathrm{A} 10 \mathrm{~L}]$ & $>>100,000$ & $(-)$ & $63,000 \pm 11,000$ & $(0.79 \pm 0.11)$ & $>>100,000$ & $(-)$ \\
\hline [P7R, A10L] & $>100,000$ & $(-)$ & $1250 \pm 300$ & $(1.00 \pm 0.23)$ & $>>100,000$ & $(-)$ \\
\hline$[\mathrm{A} 10 \mathrm{~L}, \mathrm{D} 14 \mathrm{~K}]$ & $8.2 \pm 1.2$ & $(1.01 \pm 0.11)$ & $47 \pm 9$ & & $7200 \pm 700$ & $(1.20 \pm 0.11)$ \\
\hline [L5D, P7R, A10L] & $38,000 \pm 8000$ & $(0.69 \pm 0.09)$ & $51 \pm 11$ & $(1.38 \pm 0.31)$ & $>>100,000$ & $(-)$ \\
\hline [L5D, P7R, A10V] & $6400 \pm 1300$ & $(1.04 \pm 0.22)$ & $45 \pm 11$ & $(1.35 \pm 0.42)$ & $>100,000$ & $(-)$ \\
\hline [L5R, P7D, A10L] & $56,000 \pm 2000$ & $(1.48 \pm 0.15)$ & $28,000 \pm 4000$ & $(0.91 \pm 0.09)$ & $>>100,000$ & $(-)$ \\
\hline [L5R, A10L, D14R] & $430 \pm 90$ & $(1.20 \pm 0.30)$ & $1400 \pm 100$ & $(1.27 \pm 0.16)$ & $670 \pm 50$ & $(1.20 \pm 0.19)$ \\
\hline [L5D, P7R, A10L, D14R] & $1200 \pm 250$ & $(0.73 \pm 0.10)$ & $46 \pm 8$ & $(1.44 \pm 0.28)$ & $23,000 \pm 1000$ & $(0.91 \pm 0.13)$ \\
\hline [L5R, P7D, A10L, D14R] & $4100 \pm 200$ & $(1.25 \pm 0.07)$ & $3200 \pm 100$ & $(0.73 \pm 0.12)$ & $72,000 \pm 5000$ & $(0.84 \pm 0.06)$ \\
\hline $\begin{array}{l}\text { [L5Y, P6R, P7R, A10L, } \\
\text { D14R, Y15W] }\end{array}$ & $10,000 \pm 1000$ & $(1.09 \pm 0.05)$ & $20,000 \pm 2000$ & $(1.26 \pm 0.18)$ & $19,000 \pm 1000$ & $(1.20 \pm 0.26)$ \\
\hline
\end{tabular}

Figure 2. Bar presentation of the change in potency of each analog for (a) L. stagnalis AChBP, (b) A. californica AChBP, and (c) human $\alpha 7 \mathrm{nAChR}$. This change was evaluated as logarithm of ratio of $\mathrm{IC}_{50}$ values for respective analog and PnIA[A10L]. A decrease in affinity to respective target for concrete analog as referred to PnIA[A10L] is represented in blue colored bars; and an increase - in red colored bars.

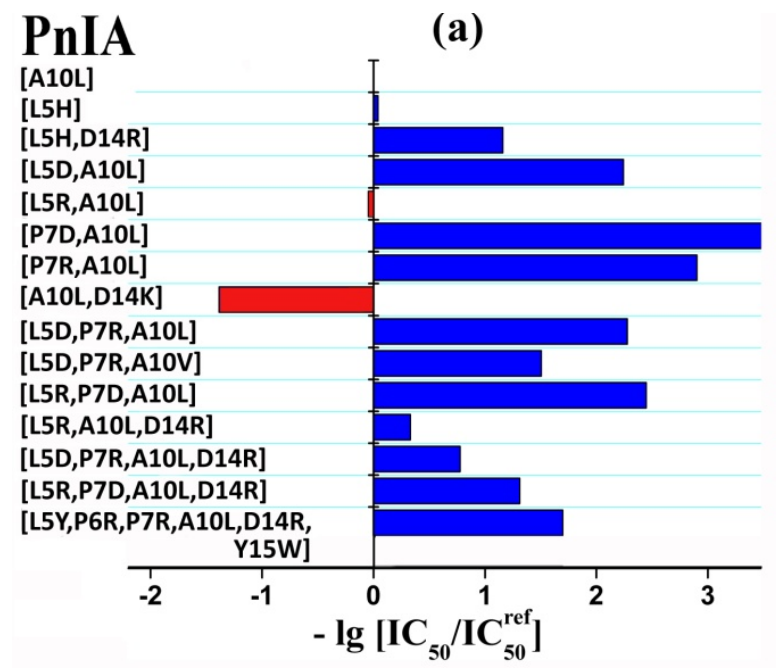

(b)

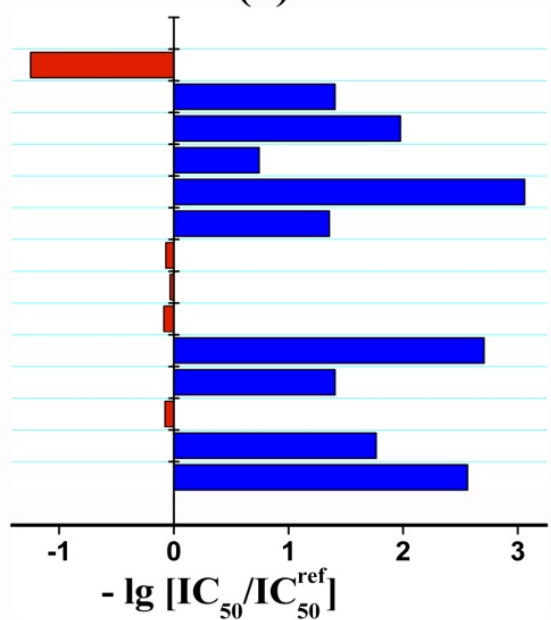

(c)

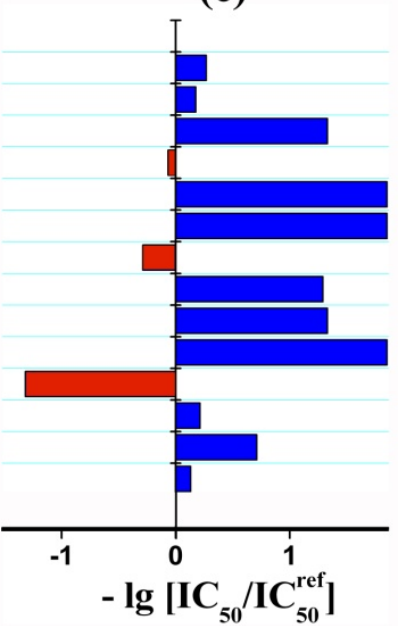


Radioligand analysis data allowed the following conclusions. Introduction of a charged residue (Arg or Asp) into positions 5 or 7 in most cases drastically decreases the affinity to all targets. The exception is PnIA[L5R, A10L], which was reported to have a 10-fold higher affinity for L. stagnalis AChBP than PnIA[A10L] [24], but in our case had only a $10 \%$ increase. We are inclined to explain this discrepancy by the essentially different procedures of displacement radioligand assay (see Experimental section).

Introduction of the same substitution may result in different effects on distinct targets. For example, a double "mutation" [L5D, P7R] did not affect the affinity for A. californica AChBP, but decreased manifold the affinity for L. stagnalis $\mathrm{AChBP}$ and $\alpha 7 \mathrm{nAChR}$. The reversed substitution [L5R, P7D] decreases the affinity for $A$. californica AChBP as well.

The computer assessment of introducing the positively charged amino acid residue in position 14 was more realistic. This additional "mutation" in some cases (PnIA[L5D, P7R, A10L, D14R]) increases the affinity for L. stagnalis $\mathrm{AChBP}$ and $\alpha 7 \mathrm{nAChR}$, but does not affect the affinity for A. californica AChBP, which is in excellent agreement with our earlier data on the activity of the PnIA[A10L, D14K] analog (see Figure 2 and [1]). A positive result of computer modeling application is the addition to this analog (which was effective but not selective among the three mentioned targets) of a more potent $\alpha 7 \mathrm{nAChR}$ ligand, namely PnIA[L5R, A10L, D14R]. On the other hand, a PnIA[L5H] analog proved to have a high affinity and selectivity for $A$. californica AChBP, with $\mathrm{IC}_{50} 3.1 \pm 0.4 \mathrm{nM}$ (Table 2). For the above-mentioned analog with three substitutions, $\mathrm{IC}_{50}$ varied in different experiments from $340 \pm 40$ to $670 \pm 50 \mathrm{nM}$.

These values need to be commented on because the $\left[{ }^{125} \mathrm{I}\right]-\alpha \mathrm{Bgt}$ displacement by $\alpha$-conotoxins from $\alpha 7 \mathrm{nAChR}$ in the $\mathrm{GH}_{4} \mathrm{C}_{1}$ cells usually is detected at micromolar concentrations. However, electrophysiology experiments, assessing the blocking effects on currents in $\alpha 7 \mathrm{nAChRs}$, gave an $\mathrm{IC}_{50}$ range of 13-260 nM for PnIA[A10L] and PnIA[A10L, D14K] [1,19]. Thus, this difference depends on the methods used. However, there are possibilities for improvement of radioligand assay results. Recalculation of the $\mathrm{IC}_{50}$ values into $\mathrm{K}_{\mathrm{i}} \mathrm{s}$ could give more appropriate affinity parameters, especially for the targets with multiple binding sites. The second possibility, is using a radioligand which would be more appropriate in structure and kinetic characteristics for testing the competition of $\alpha$-conotoxins. Almost irreversible binding of $\left[{ }^{125} \mathrm{I}\right]-\alpha \mathrm{Bgt}$ makes the detection of competition for $\alpha$-conotoxins quite difficult, having fast dissociation rates from the target surface. That is why it is desirable to assess binding of novel $\alpha$-conotoxins in displacement not only of $\left[{ }^{125} \mathrm{I}\right]-\alpha \mathrm{Bgt}$, but of the radioactive $\alpha$-conotoxins as well. We have earlier used such an approach for a number of $\alpha$-conotoxins acting on the muscle-type nAChR [27,39] and in the present work: the three above-mentioned $\alpha$-conotoxin analogs, (PnIA[A10L, D14K], PnIA[L5H] and PnIA[L5R, A10L, D14R]), were radioiodinated.

\subsection{Experiments with Radioactive Forms of $\alpha$-Conotoxin Analogs}

\subsubsection{Preparation of Radioactive Derivatives}

Chemical modification of PnIA[A10L, D14K], PnIA[L5H] and PnIA[L5R, A10L, D14R] in the presence of chloramine $\mathrm{T}$ gave their $\left[{ }^{125} \mathrm{I}\right]$-labeled derivatives. Iodine incorporates mostly to the Tyr 15 phenol group, and for each iodinated peptide both mono- and di-iodinated derivatives were formed and 
then separated by reverse-phase HPLC. Figure 3 shows the separation of the iodinated derivatives after modification of PnIA[L5R, A10L, D14R] with nonradioactive isotope $\left[{ }^{127} \mathrm{I}\right]$. Iodinated derivatives of the other two $\alpha$-conotoxins were prepared and separated in a similar way. The structures of all iodinated derivatives were confirmed by MALDI-TOF mass-spectrometry (found masses $\mathrm{MH}^{+}$shown in Figure 3 are exactly the same as calculated).

Figure 3. HPLC profile for the products of the $\left[{ }^{127} \mathrm{I}\right]$ iodination reaction of PnIA[L5R, A10L, D14R] analog. The peaks of oxidizer (chloramine T), non-modified analog and mono- and di-iodinated derivatives are marked with indicated molecular masses $\left(\mathrm{MH}^{+}\right)$ measured by MALDI mass-spectrometry.

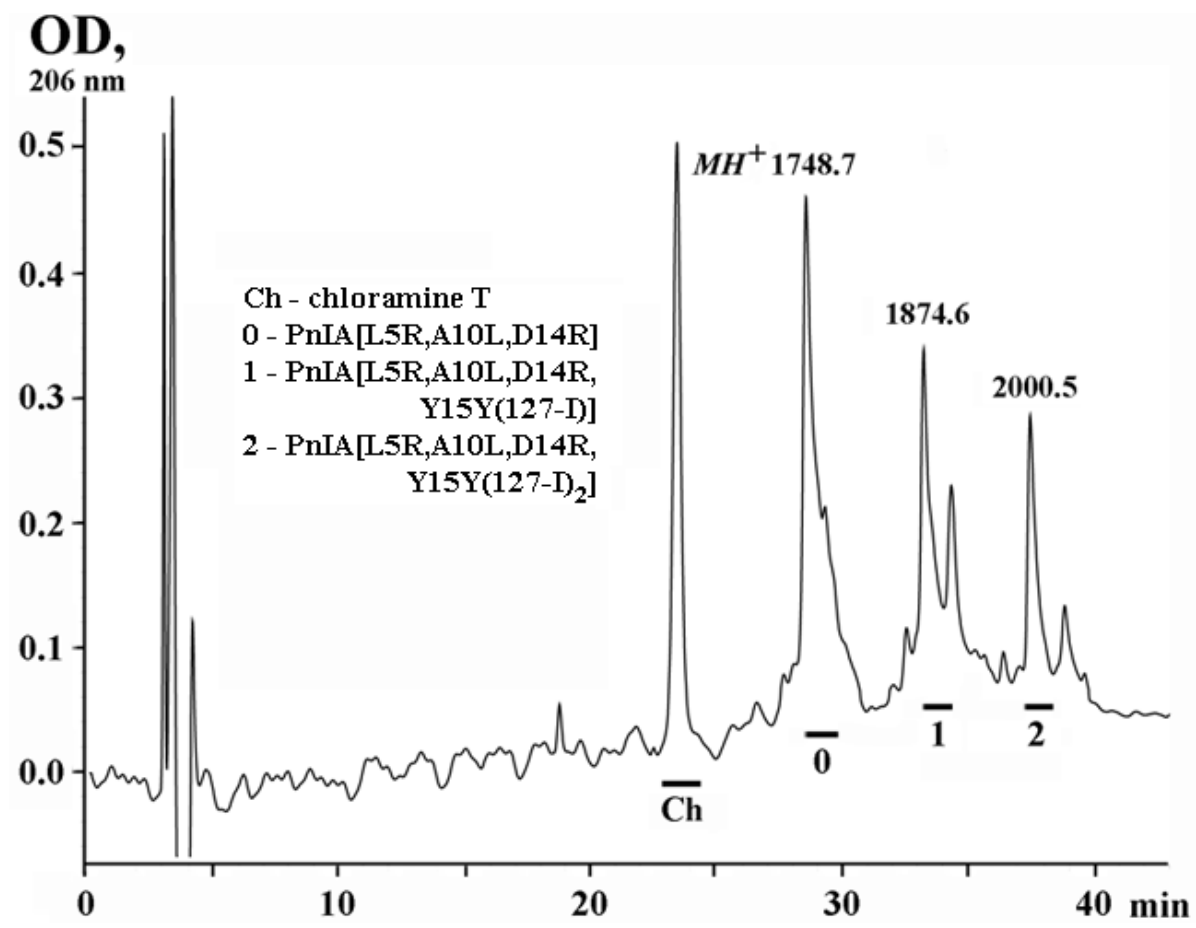

Using this scheme and $\left[{ }^{125} \mathrm{I}\right]$ we prepared the PnIA [A10L, D14K] and PnIA [L5H] iodinated derivatives with the specific radioactivity of 2000 and $4000 \mathrm{Ci} / \mathrm{mmol}$ for mono- and di-iodinaned compounds, respectively. Taking into account the acting concentrations of PnIA [L5R, A10L, D14R] (see Table 2), its iodination was done with a mixture of $\left[{ }^{125} \mathrm{I}\right]$ and $\left[{ }^{127} \mathrm{I}\right]$ isotopes resulting in mono and di-iodinated products with the specific radioactivity $\sim 5$ and $10 \mathrm{Ci} / \mathrm{mmol}$. In further experiments only mono-iodinated derivatives were used.

\subsubsection{Direct Radioligand Assay}

In the direct radioligand assay, [ $\left.{ }^{125} \mathrm{I}\right]-\mathrm{PnIA}[\mathrm{A} 10 \mathrm{~L}, \mathrm{D} 14 \mathrm{~K}]$ revealed a capacity to bind with both AChBPs with sub-nanomolar affinity (Figure $4 \mathrm{a}$ ), $K_{\mathrm{D}}$ being $0.53 \pm 0.17 \mathrm{nM}$ and $0.36 \pm 0.10 \mathrm{nM}$ for L. stagnalis and A. californica AChBPs, respectively. [ $\left.{ }^{125} \mathrm{I}\right]$-PnIA[L5H] (Figure 4b) showed similar high affinity for A. californica $\mathrm{AChBP}\left(K_{\mathrm{D}} 0.48 \pm 0.20 \mathrm{nM}\right)$ and, in addition, demonstrated a high selectivity without interacting under the same conditions with L. stagnalis AChBP or human $\alpha 7 \mathrm{nAChR}$. 
Figure 4. Specific binding curves of $\left[{ }^{125} \mathrm{I}\right]$-labeled derivatives of (a) PnIA[A10L, D14K], (b) PnIA[L5H], and (c) PnIA[L5R, A10L, D14R] to AChBPs (from L. stagnalis (•) or A. californica (O)), A. californica AChBP and human $\alpha 7 \mathrm{nAChR}$, respectively. Data from just one experiment (with mean \pm s.e. of duplicate or triplicate for each point $(n=2$ or 3$)$ ) are represented; the respective $K_{\mathrm{D}}$ values were (a) $0.53 \pm 0.17$ and $0.36 \pm 0.10 \mathrm{nM}$; (b) $0.48 \pm 0.2 \mathrm{nM}$; and (c) $190 \pm 130 \mathrm{nM}$.

(a)

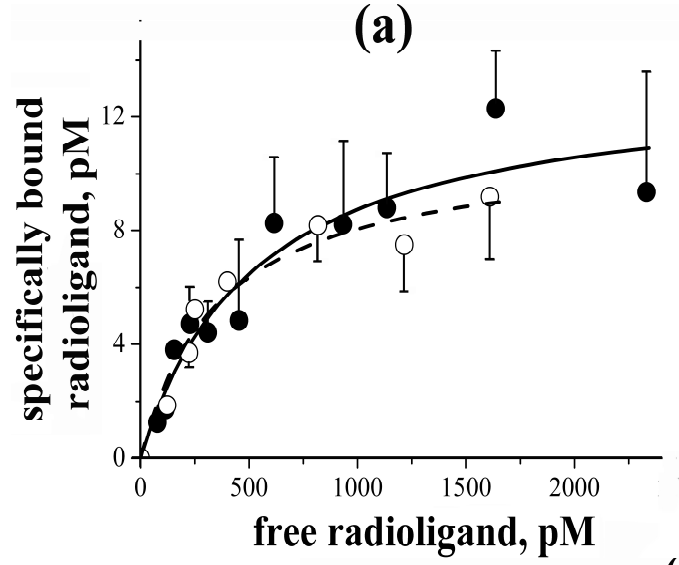

(c) (b)
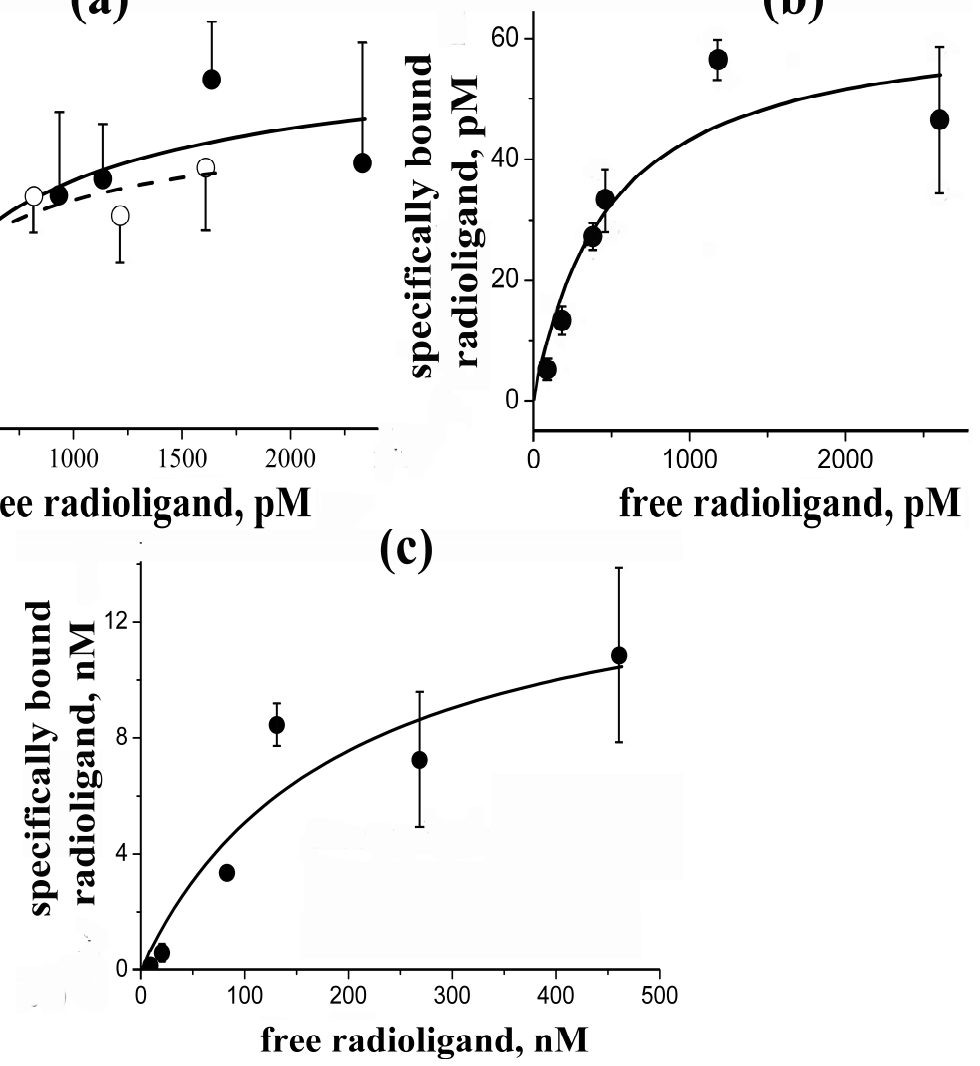

Iodinated PnIA[L5R, A10L, D14R] showed specific binding to $\alpha 7 \mathrm{nAChR}$ (Figure 4c), but also had a very high nonspecific binding to the $\mathrm{GH}_{4} \mathrm{C}_{1}$ cells; the reasons for which are unclear. This made difficult accurate determination of the $K_{\mathrm{D}}$ values which in different experiments varied from $190 \pm 130 \mathrm{nM}$ (Figure 4c) to $\sim 1600 \pm 800 \mathrm{nM}$ (mean \pm s.e.); the averaged value from all experiments being $\sim 900 \pm 600 \mathrm{nM}$ (mean \pm s.e.m. for $n=6$ ).

In all cases, the measured $K_{\mathrm{D}}$ values are in good agreement with the $\mathrm{IC}_{50}$ values found for the starting non-iodinated $\alpha$-conotoxins in competition with $\left[{ }^{125} \mathrm{I}\right]-\alpha$ Bgt. It shows the applicability of radioiodinated $\alpha$-conotoxins both for labeling the respective targets and for analysis of binding capacities for novel $\alpha$-conotoxins. To verify the latter, we analyzed binding of several compounds in competition with $\left[{ }^{125} \mathrm{I}\right]-\mathrm{PnIA}[\mathrm{L} 5 \mathrm{H}]$ and $\left[{ }^{125} \mathrm{I}\right]-\mathrm{PnIA}[\mathrm{L} 5 \mathrm{R}, \mathrm{A} 10 \mathrm{~L}, \mathrm{D} 14 \mathrm{R}]$ and compared results to same in competition with $\left[{ }^{125} \mathrm{I}\right]-\alpha \mathrm{Bgt}$.

\subsubsection{Competition Radioligand Assay with $\left[{ }^{125} \mathrm{I}\right]$-Labeled Derivatives of $\alpha$-Conotoxins}

The results for $\left[{ }^{125} \mathrm{I}\right]-\mathrm{PnIA}[\mathrm{L} 5 \mathrm{H}]$ and $\left[{ }^{125} \mathrm{I}\right]-\alpha \mathrm{Bgt}$ on $A$. californica AChBP are shown in Figure 5a,b and the calculated $\mathrm{IC}_{50}$ values are given in Table 3 . For $\alpha$-conotoxin PnIA[L5H], these values 
practically coincide, while all the other compounds in competition with radioactive $\alpha$-conotoxin show 5-30-fold higher affinity. $\alpha \mathrm{Bgt}$ in competition with the radioactive $\alpha$-conotoxin had less activity against $A$. californica AChBP, as earlier found in competition with $\left[{ }^{125} \mathrm{I}\right]-\alpha \mathrm{Bgt}$ [1]. $\alpha$-Conotoxin GI acting on muscle-type nAChR was inactive in both cases. It should be emphasized that using $\left[{ }^{125} \mathrm{I}\right]$-labeled $\alpha$-conotoxin instead of $\left[{ }^{125} \mathrm{I}\right]$ - $\alpha$ Bgt gives better $\mathrm{IC}_{50}$ values for tested $\alpha$-conotoxins which, because of their closer relation to the $\alpha$-conotoxin radioligand, better reflects their affinity for the respective target.

Figure 5. Inhibition of $\left[{ }^{125} \mathrm{I}\right]$-labeled derivatives of (a) PnIA[L5H], and (b) $\alpha$-bungarotoxin $(\alpha \mathrm{Bgt})$ binding to $A$. californica AChBP with indicated $\alpha$-conotoxins and $\alpha \mathrm{Bgt}$ : (1) $\alpha$-conotoxin PnIA[L5H] (filled circles, thick line), (2) $\alpha$-conotoxin PnIA[A10L] (thin line), (3) $\alpha$-conotoxin GI (open circles, thin line) and (4) $\alpha$ Bgt (dot line). The curves were calculated from the data of the means of four or five $(n=4$ or 5$)$ independent experiments in duplicate for each point. For simplicity the mean \pm s.e.m. are presented only for $\mathrm{PnIA}[\mathrm{L} 5 \mathrm{H}]$ analog. The respective $\mathrm{IC}_{50}$ values are listed in Table 3.

(a)

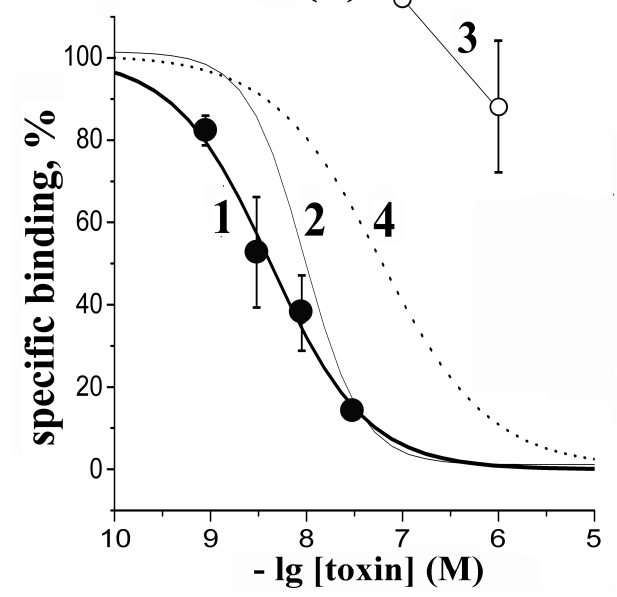

(b)

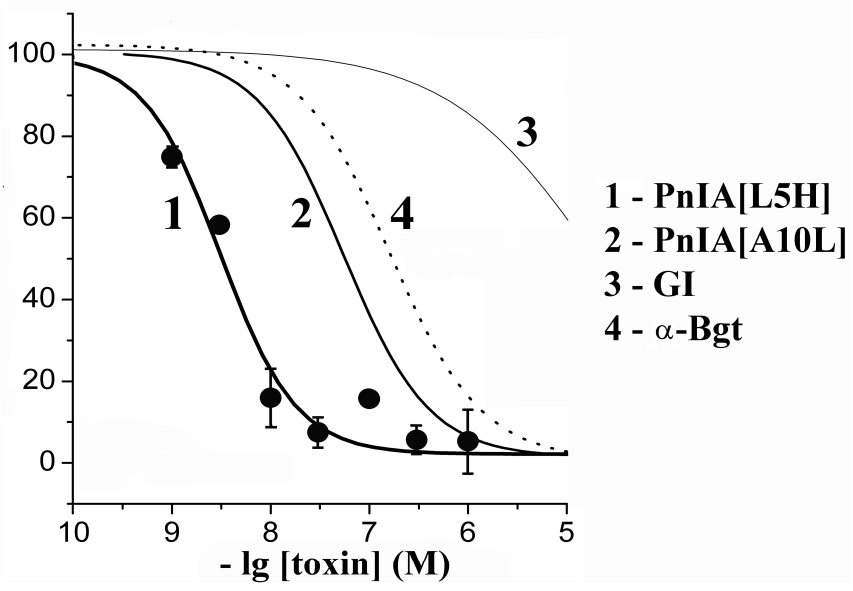

Table 3. Potency (presented as $\mathrm{IC}_{50}$ values in $\mathrm{nM}$ ) and Hill coefficients $\left(n_{\mathrm{H}}\right)$ of some $\alpha$-conotoxins and $\alpha$-conotoxin PnIA analogs, tested in competition with $\left[{ }^{125} \mathrm{I}\right]$-labeled PnIA[L5H] or $\left[{ }^{125} \mathrm{I}\right]-\alpha \mathrm{Bgt}$ for binding to A. californica AChBP (see respective inhibition curves in Figure 5), calculated using ORIGIN 7.5 with the mean \pm s.e.m. of duplicate data obtained in $n=4$ or 5 independent experiments.

\begin{tabular}{|l|l|l|l|l|}
\hline \multirow{2}{*}{ Compound } & \multicolumn{3}{|c|}{ IC $_{\mathbf{5 0}}$ in $\mathbf{n M}$ and Hill slopes $\left(\boldsymbol{n}_{\mathbf{H}}\right)$ in competition with } \\
\cline { 2 - 5 } & \multicolumn{2}{|c|}{$\left[{ }^{\mathbf{1 2 5}} \mathbf{I}\right]-\mathbf{P n} \mathbf{I}[\mathbf{L 5 H}]$} & \multicolumn{2}{c|}{$\left[{ }^{\mathbf{1 2 5}} \mathbf{I}\right]-\mathbf{\alpha B g t}$} \\
\hline PnIA[L5H] & $4.2 \pm 0.3$ & $(0.87 \pm 0.05)$ & $3.1 \pm 0.4$ & $(1.13 \pm 0.15)$ \\
\hline PnIA[A10L] & $9.5 \pm 1.1$ & $(1.40 \pm 0.20)$ & $36-55^{*}$ & \\
\hline PnIA[A10L, D14K] & $2.2 \pm 0.6$ & $(1.42 \pm 0.49)$ & $28-47 *$ & \\
\hline$\alpha$-conotoxin ImI & $0.84 \pm 0.15$ & $(1.37 \pm 0.29)$ & $33 \pm 5 * *$ & \\
\hline$\alpha$-conotoxin GI & $>>1000$ & $(-)$ & $25,500 \pm 6300 * *$ & \\
\hline$\alpha$-bungarotoxin $(\alpha \mathrm{Bgt})$ & $60 \pm 10$ & $(0.77 \pm 0.08)$ & $130 \pm 20 * *$ & \\
\hline
\end{tabular}

* dispersion of the mean $\mathrm{IC}_{50}$ values in this study and experiments carried out by us earlier [1];

** data from [1]. 
Similar results were obtained for $\left[{ }^{125} \mathrm{I}\right]-\mathrm{PnIA}[\mathrm{L} 5 \mathrm{R}, \mathrm{A} 10 \mathrm{~L}, \mathrm{D} 14 \mathrm{R}]$ and $\left[{ }^{125} \mathrm{I}\right]-\alpha \mathrm{Bgt}$ binding to human $\alpha 7 \mathrm{nAChR}$ in the $\mathrm{GH}_{4} \mathrm{C}_{1}$ cell line. Here we compared the most efficient ligands in our series acting on this receptor (Figure 6 and Table 4). The ratio of their affinities was the same in both cases, while the $\mathrm{IC}_{50}$ values were considerably lower when measured with radioactive $\alpha$-conotoxin PnIA analog.

Figure 6. Inhibition of $\left[{ }^{125} \mathrm{I}\right]$-labeled derivatives of (a) PnIA[L5R, A10L, D14R], and (b) $\alpha$ Bgt binding to human $\alpha 7 \mathrm{nAChR}$ with (1) PnIA[L5R, A10L, D14R] (filled circles, thick line) and (2) PnIA[A10L, D14K] (open circles, dashed line). The curves were calculated from the data of the mean of three $(n=3)$ or five $(n=5)$ independent experiments in duplicate for each point in the first or second case, respectively. The calculated $\mathrm{IC}_{50}$ values are listed in Table 4.

(a)

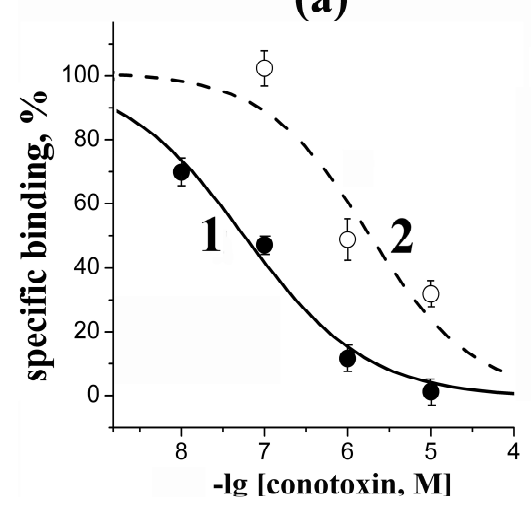

(b)

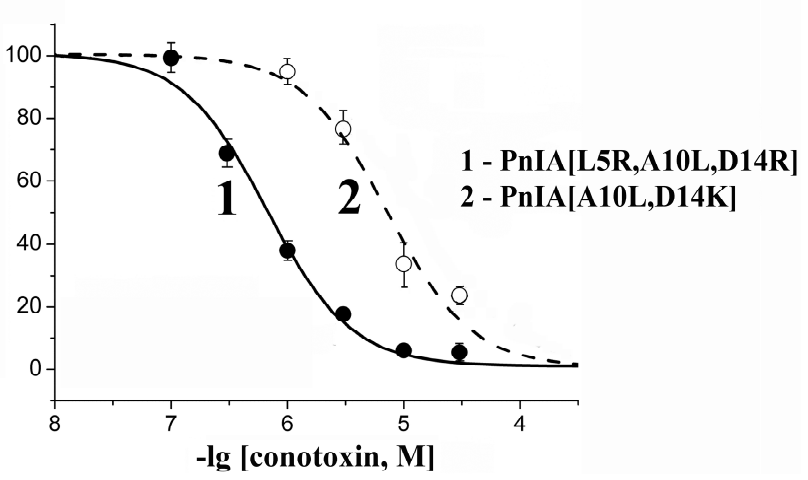

Table 4. Potency (presented as the $\mathrm{IC}_{50}$ values in $\mathrm{nM}$ ) and Hill coefficients $\left(n_{\mathrm{H}}\right)$ of PnIA[L5R, A10L, D14R] and PnIA[A10L, D14K] analogs, tested in competition with $\left[{ }^{125} \mathrm{I}\right]$-labeled PnIA[L5R, A10L, D14R] or $\left[{ }^{125} \mathrm{I}\right]-\alpha \mathrm{Bgt}$ for binding to human $\alpha 7 \mathrm{nAChR}$ (see respective inhibition curves shown in Figure 6). The data were calculated using ORIGIN 7.5 with the mean \pm s.e.m. of duplicate data obtained in $n=3$ or 5 independent experiments, respectively.

\begin{tabular}{|l|l|l|l|l|}
\hline \multirow{2}{*}{ Compound } & \multicolumn{3}{|c|}{ IC $_{50}$ in $\mathbf{n M}$ and Hill slopes $\left(\boldsymbol{n}_{\mathbf{H}}\right)$ in competition with } \\
\cline { 2 - 5 } & $\left.{ }^{\mathbf{1 2 5}} \mathbf{I}\right]-$ PnIA[L5R, A10L, D14R] & \multicolumn{2}{|c|}{$\left[^{\mathbf{1 2 5}} \mathbf{I}\right]-\mathbf{\alpha B g t}$} \\
\hline PnIA[L5R, A10L, D14R] & $60 \pm 7$ & $(0.65 \pm 0.05)$ & $670 \pm 50$ & $(1.20 \pm 0.19)$ \\
\hline PnIA[A10L, D14K] & $1800 \pm 600$ & $(0.75 \pm 0.14)$ & $7200 \pm 700$ & $(1.20 \pm 0.11)$ \\
\hline
\end{tabular}

Choosing which $\alpha$-conotoxin analogs to synthesize, we relied upon computer modeling and simple docking algorithms [1,27-29], without performing molecular dynamics. As shown in this paper, only three out of 14 chosen compounds gave results which agreed with the predictions. We have earlier described that docking predictions for $\alpha$-conotoxin ImII agreed only in part with the experimental results obtained for the AChBPs, muscle and neuronal nAChRs with the aid of radioligand analysis, electrophysiology and surface plasmon resonance [40]. One of the reasons may be that amino acid substitutions in $\alpha$-conotoxins, or mutations in the receptor binding site of a particular receptor subtype, may induce a change in the ligand orientation. This means that some of the interactions which were expected to take place as a result of the introduced receptor mutations or changes in the ligand structure, did not take place. Indeed, a small change in the orientation of the $\alpha$-conotoxins in the 
binding site of the A. californica AChBP was observed when comparing the X-ray structures for complexes of PnIA[A10L, D14K] and $\alpha$-conotoxin TxIA[A10L] which have very similar chemical and spatial structures $[1,24]$. It has recently been shown that, according to photo-crosslinking data, bound azido-epibatidine has one orientation in the muscle-type $\mathrm{nAChR}$, and two orientations, differing by $180^{\circ}$, in the $\alpha 4 \beta 2 \mathrm{nAChR}$ [41]. Moreover, recent X-ray structures of the A. californica AChBP complexes with d-tubocurarine and strychnine, revealed not only their different orientations in the five binding sites of the same AChBP molecule, but even the presence of two ligands in some of them [42]. These results clearly show that more efficient use of computer modeling is necessary, as well as application of molecular dynamics and other mathematical approaches [42].

In spite of the discussed limitations, the main result of this work is that we have synthesized several $\alpha$-conotoxins which might be useful both for fundamental research on nAChRs and for practical application. First of all, we should mention radioiodinated $\alpha$-conotoxins for use in binding assays with distinct AChBPs. Among them there are the compounds which have $K_{\mathrm{D}} \sim 0.3-0.5 \mathrm{nM}$ in binding to AChBPs, which is among the highest affinities known for $\alpha$-conotoxins. The affinity of radioiodinated $\alpha$-conotoxin PnIA[L5R, A10L, D14R] is also relatively high for $\alpha 7 \mathrm{nAChR}$, but a high level of nonspecific binding hampers practical application of this analog. However, what is more important for radioiodinated $\alpha$-conotoxins is not the affinity as such, but their usefulness in assessing the activity of other $\alpha$-conotoxins in competition tests. Tables 3 and 4 show that for the majority of analyzed $\alpha$-conotoxins, their $\mathrm{IC}_{50}$ values, measured in competition with radioactive $\alpha$-conotoxins, are about 10 -times lower than those found in competition with $\left[{ }^{125} \mathrm{I}\right]$ - $\alpha$ Bgt. Thus, a combination of AChBPs with radioiodinated $\alpha$-conotoxins appears to be very promising for testing new $\alpha$-conotoxins, because it has distinct advantages over $\left[{ }^{125} \mathrm{I}\right]-\alpha \mathrm{Bgt}$ with its virtually irreversible binding.

\section{Experimental Section}

\subsection{Computer Modeling}

In this study we used partial comparative modeling under MODELLER 7v7 program [43]. The model of $\alpha 7 \mathrm{nAChR}$ was built using Swiss-Prot Server [44]. The programs DOCK [45], HEX [46], AUTODOCK [47], HADDOCK [48] were used for intermolecular docking simulations and energy calculations. Solutions that contradicted known pair-wise interactions were rejected. The detailed description for computer modeling and docking was published by us elsewhere $[1,29]$.

\subsection{Peptide Synthesis}

Solid-phase peptide synthesis was used for preparation of all $\alpha$-conotoxin PnIA analogs. We applied two different approaches. The first one was the synthesis using the same trityl protection of the cysteine thiol groups followed by simultaneous deprotection and closing the disulfides. In the cases of formation of the second Cys-Cys isomer (in amounts of more than 15\%), we carried out the synthesis with the use of the different protection groups for respective cysteine pairs and selective formation of the disulfides. The first protocol was utilized many times for preparation of various $\alpha$-conotoxins and their analogs and was described in detail in [49]; the second one was given in full in [27], where it was applied for PnIA[A10L, D14K] synthesis. 


\subsection{Iodination}

Before preparation of radiolabeled derivatives of PnIA[A10L, D14K], PnIA[L5H] and PnIA[L5R, A10L, D14R] we carried out a series of experiments with nonradioactive $\left[{ }^{127} \mathrm{I}\right]$-isotope to optimize the reaction and purification conditions, as well as to confirm the structures of iodinated products by MALDI TOF mass spectrometry. Peptides (3-5 nmoles) dissolved in $15 \mu \mathrm{L}$ of $125 \mathrm{mM}$ sodium phosphate buffer, $\mathrm{pH} 7.2$, were incubated $15 \mathrm{~min}$ at room temperature with 3-5 nmoles of NaI (in $4 \mu \mathrm{L}$ of the same buffer) and 4-10-fold molar excess of chloramine $\mathrm{T}$ (solved in $1 \mu \mathrm{L}$ of water). Reaction products were separated by reverse-phase HPLC in aqueous gradient of acetonitrile containing $0.1 \%$ trifluoroacetic acid. The best separation of the reaction products were obtained: for PnIA[A10L, D14K] on a column Nucleosil $\mathrm{C}_{18}(250 \times 4.6 \mathrm{~mm})$ at a rate of $1 \mathrm{~mL} / \mathrm{min}$ in acetonitrile gradient $10-50 \%$ for 40 min; for PnIA[L5H] and PnIA[L5R, A10L, D14R] (see Figure 2) on a column Reprosil C 18 AQ (5 $\mu$; $150 \times 4 \mathrm{~mm}$ ) at a rate of $0.5 \mathrm{~mL} / \mathrm{min}$ and acetonitrile gradient $15-35 \%$ for $40 \mathrm{~min}$ and $10-40 \%$ for 60 min, respectively. Purified peaks were analyzed by MALDI TOF mass spectrometry resulting in identification of non-modified, mono- and di-[ $\left[{ }^{127} \mathrm{I}\right]$-iodinated compounds.

The similar protocols (but with different amounts of reaction components) were applied for preparation of radioactive derivatives using $\mathrm{Na}\left[{ }^{125} \mathrm{I}\right]$ solution:

120 pmoles PnIA[A10L, D14K] +90 pmoles Na $\left.{ }^{125} \mathrm{I}\right]+1000$ pmoles chloramine $\mathrm{T}$

or

80 pmoles PnIA[L5H] +65 pmoles $\mathrm{Na}\left[{ }^{125} \mathrm{I}\right]+4.4$ nmoles chloramine $\mathrm{T}$

For PnIA[L5R, A10L, D14R] analog we used the isotopic mixture of $\mathrm{Na}\left[{ }^{125} \mathrm{I}\right]$ and $\mathrm{Na}\left[{ }^{127} \mathrm{I}\right]$ at the ratio of $1: 333$, so the reaction protocol was:

9.6 nmoles PnIA[L5R, A10L, D14R] + 10 nmoles Na[ $\left.{ }^{125+127} \mathrm{I}\right]+44$ nmoles chloramine T

Reaction products were separated by HPLC under above-mentioned conditions and collected in 0.5 min-fractions. The aliquots of all fractions were counted on $\gamma$-counter and mono- and di- $\left[{ }^{125} \mathrm{I}\right]$ iodinated derivatives (with approximate specific radioactivity of 2000 and $4000 \mathrm{Ci} / \mathrm{mmol}$ ) of PnIA[A10L, D14K] and PnIA[L5H] analogs as well as PnIA[L5R, A10L, D14R] analog (with approximate specific radioactivity of 6 and $12 \mathrm{Ci} / \mathrm{mmol}$ ) were collected in respective united samples. These samples were evaporated (approximately to $50 \%$ of initial volume) to remove acetonitrile and were kept at $4{ }^{\circ} \mathrm{C}$ in $50 \mathrm{mM}$ Tris-HC1 buffer, $\mathrm{pH} 7.5$, containing $0.1 \mathrm{mg} / \mathrm{mL}$ BSA.

We only used mono-[ $\left.{ }^{125} \mathrm{I}\right]$ iodinated derivatives of all analogs in our studies.

\subsection{Radioligand Assay}

In competition experiments with $\left[{ }^{125} \mathrm{I}\right]$ - $\alpha \mathrm{Bgt}$, all synthesized $\alpha$-conotoxin PnIA analogs (concentration range for concrete peptide was varied inside 1-100,000 $\mathrm{nM}$ ) were pre-incubated $2.0-2.5 \mathrm{~h}$ at room temperature with the L. stagnalis or A. californica AChBPs (final concentrations of 2.4 and $140 \mathrm{nM}$, respectively) in $50 \mu \mathrm{L}$ of buffer A (phosphate-buffered saline, $0.7 \mathrm{mg} / \mathrm{mL}$ of bovine serum albumin, $0.05 \%$ Tween $20, \mathrm{pH} 7.5$ ) or with the $\mathrm{GH}_{4} \mathrm{C}_{1}$ cells (final $6.5 \mu \mathrm{g}$ of total protein with $0.4 \mathrm{nM}$ of toxin-binding sites) in $50 \mu \mathrm{L}$ of buffer B $(20 \mathrm{mM}$ Tris- $\mathrm{HCl}$ buffer, $1 \mathrm{mg} / \mathrm{mL}$ of bovine serum albumin, 
$\mathrm{pH}$ 8.0). After that, $\left[{ }^{125} \mathrm{I}\right]-\alpha \mathrm{Bgt}$ was added to L. stagnalis AChBP, A. californica $\mathrm{AChBP}$ or $\mathrm{GH}_{4} \mathrm{C}_{1}$ cells at final concentration $0.1,0.3$ or $0.2 \mathrm{nM}$ and the mixtures were additionally incubated for $30 \mathrm{~min}$, $30 \mathrm{~min}$ or $5 \mathrm{~min}$, respectively. The specific binding was determined by rapid filtration on double DE-81 filters (Whatman) pre-soaked in buffer A (for AChBPs) or on GF/F filters (Whatman) pre-soaked in $0.25 \%$ polyethylenimine (for $\mathrm{GH}_{4} \mathrm{C}_{1}$ cells) and the unbound radioactivity was removed from the filters by washes $(3 \times 3 \mathrm{~mL})$ with the buffers $\mathrm{A}$ and $\mathrm{B}$, respectively. Non-specific binding was determined in all cases in the presence of $2 \mu \mathrm{M} \alpha$-cobratoxin (2.0-2.5 h pre-incubation).

In competition experiments with $\left[{ }^{125} \mathrm{I}\right]-\mathrm{PnIA}[\mathrm{L} 5 \mathrm{H}]$, selected $\alpha$-conotoxin PnIA analogs or $\alpha$-Bgt (concentration range for concrete compound varied within 1-1000 nM) were pre-incubated $1.5 \mathrm{~h}$ at room temperature with the A. californica AChBP (final concentration of $2.3 \mathrm{nM}$ ) in $50 \mu \mathrm{L}$ of buffer A followed by adding radioligand (final $0.6-1.0 \mathrm{nM}$ ) and additional incubation during $1 \mathrm{~h}$. Non-specific binding was determined in the presence of $3.8 \mu \mathrm{M} \alpha$-cobratoxin. The filtration was performed as mentioned above for experiments with $\left[{ }^{125} \mathrm{I}\right]-\alpha \mathrm{Bgt}$ on the AChBPs.

In competition experiments with [ $\left.{ }^{125} \mathrm{I}\right]-\mathrm{PnIA}[\mathrm{L} 5 \mathrm{R}, \mathrm{A} 10 \mathrm{~L}, \mathrm{D} 14 \mathrm{R}]$, two analogs-PnIA[A10L, D14K] and PnIA[L5R, A10L, D14R] (from 10 to 30,000 nM) —were incubated $1.5 \mathrm{~h}$ at room temperature and permanent shaking with $\mathrm{GH}_{4} \mathrm{C}_{1}$ cells $(0.4 \mathrm{nM}$ of toxin-binding sites of $\alpha 7 \mathrm{nAChR})$ in $50 \mu \mathrm{L}$ of buffer $\mathrm{B}$. After that, radioligand (final concentration of $180 \mathrm{nM}$ ) was added and the reaction mixture was incubated additional $1.5 \mathrm{~h}$ under the same conditions. Non-specific binding was determined by $1.5 \mathrm{~h}$ pre-incubation with $25 \mu \mathrm{M} \alpha$-cobratoxin. The filtration was performed as mentioned above for experiments with $\left[{ }^{125} \mathrm{I}\right]-\alpha \mathrm{Bgt}$ on the $\mathrm{GH}_{4} \mathrm{C}_{1}$ cells.

Competition data analyses were fit using ORIGIN 7.5 (OriginLab Corporation, Northampton, MA, USA) to a one-site dose-response curve by Equation: \% response $=100 /\left\{1+\left([\text { toxin }] / \mathrm{IC}_{50}\right)^{n_{\mathrm{H}}}\right\}$, where $\mathrm{IC}_{50}$ is the concentration at which $50 \%$ of the sites are inhibited and $n_{\mathrm{H}}$ is the Hill coefficient.

Equilibrium binding of $\left[{ }^{125} \mathrm{I}\right]-\mathrm{PnIA}[\mathrm{A} 10 \mathrm{~L}, \mathrm{D} 14 \mathrm{~K}]$ with both AChBPs (final concentration $1.2 \mathrm{nM}$ ) was carried out in $50 \mu \mathrm{L}$ of buffer $\mathrm{A}$ at room temperature. Various concentrations of radioligand $(0.05-2.5 \mathrm{nM})$ were incubated with proteins for $30 \mathrm{~min}$. Non-specific binding was determined in the presence of $\alpha$-cobratoxin at a 500 -fold molar excess over the radioligand ( $1 \mathrm{~h}$ pre-incubation). The filtration was performed as mentioned above for AChBPs.

The similar protocol was applied for equilibrium binding of $\left[{ }^{125} \mathrm{I}\right]-\mathrm{PnIA}[\mathrm{L} 5 \mathrm{H}]$ with A. californica AChBP. We incubated in this case $0.1-2.8 \mathrm{nM}$ of radioligand with $2.3 \mathrm{nM}$ of protein during $2 \mathrm{~h}$ at room temperature. Non-specific binding was determined by $1 \mathrm{~h}$ pre-incubation with $3.8 \mu \mathrm{M} \alpha$-cobratoxin.

Equilibrium binding of $\left[{ }^{125} \mathrm{I}\right]-\mathrm{PnIA}[\mathrm{L} 5 \mathrm{R}, \mathrm{A} 10 \mathrm{~L}, \mathrm{D} 14 \mathrm{R}]$ with human $\alpha 7 \mathrm{nAChR}$ transfected in rat $\mathrm{GH}_{4} \mathrm{C}_{1}$ cell line was carried out in $50 \mu \mathrm{L}$ of buffer $\mathrm{B}$ at room temperature during $1.5 \mathrm{~h}$ with permanent shaking. Various concentrations of radioligand $(6-1600 \mathrm{nM})$ were incubated with $0.4 \mathrm{nM}$ of toxin-binding sites of $\alpha 7 \mathrm{nAChR}$. Non-specific binding was determined by $1.5 \mathrm{~h}$ pre-incubation with $25 \mu \mathrm{M} \alpha$-cobratoxin. The specific binding was determined by rapid filtration on $\mathrm{GF} / \mathrm{F}$ or $\mathrm{GF} / \mathrm{C}$ filters pre-soaked in $0.25 \%$ polyethylenimine and the unbound radioactivity was removed from the filters by washes $(3 \times 3 \mathrm{~mL})$ with the buffer B.

Equilibrium binding data were fit using ORIGIN 7.5 to a one-site model according to Equation: $B(x)=B_{\max } /\left(1+K_{\mathrm{D}} / x\right)$, where $B(x)$ is the radioligand specifically bound at a free concentration $x$ (determined by subtraction of the amount of bound and adsorbed radioligand from the total amount 
added to incubation mixture), $B_{\max }$ is the maximal specific bound radioligand, and $K_{\mathrm{D}}$ is the dissociation constant.

\section{Conclusions}

Our work demonstrates that the available X-ray structures of AChBP complexes with $\alpha$-conotoxins are a good starting point for design and subsequent synthesis of novel $\alpha$-conotoxins having higher affinity and desired selectivity. In fact, we prepared several analogs of higher affinity, better discriminating the AChBPs from A. californica and L. stagnalis. Our achievements are more modest for $\alpha$-conotoxins targeting the $\alpha 7 \mathrm{nAChR}$, apparently because no X-ray structure is available either for this receptor or for its extracellular ligand-binding domain, and the used computer modeling and docking approaches were insufficient to take into account possible multiple orientations of bound $\alpha$-conotoxin analogs. However, by preparing radioiodinated derivatives of several synthesized analogs, we demonstrated that the competition with such radioactive $\alpha$-conotoxins is a better way to test new $\alpha$-conotoxins than the radioligand analysis with radioiodinated $\alpha$-bungarotoxin.

\section{Acknowledgements}

The authors are grateful to T. Sixma (Netherlands Cancer Institute, Amsterdam) for AChBPs and to EliLilly (London) for $\mathrm{GH}_{4} \mathrm{C}_{1}$ cells transfected with human $\alpha 7 \mathrm{nAChR}$. The work was supported by RFBR Grant \#09-04-01476 and by FP7 Grant "Neurotransmitter Cys-loop receptors: structure, function and disease". The authors are also grateful to D. Mordvintsev for the help with computer modeling and docking procedures.

\section{References}

1. Celie, P.H.N.; Kasheverov, I.E.; Mordvintsev, D.Y.; Hogg, R.C.; van Nierop, P.; van Elk, R.; van Rossum-Fikkert, S.E.; Zhmak, M.N.; Bertrand, D.; Tsetlin, V.; et al. Crystal structure of nicotinic acetylcholine receptor homolog AChBP in complex with an $\alpha$-conotoxin PnIA variant. Nat. Struct. Mol. Biol. 2005, 12, 582-588.

2. Nicke, A.; Wonnacott, S.; Lewis, R.J. $\alpha$-Conotoxins as tools for the elucidation of structure and function of neuronal nicotinic acetylcholine receptor subtypes. Eur. J. Biochem. 2004, 271, 2305-2319.

3. Janes, R.W. $\alpha$-Conotoxins as selective probes for nicotinic acetylcholine receptor subclasses. Curr. Opin. Pharmacol. 2005, 5, 280-292.

4. Olivera, B.M.; Quik, M.; Vincler, M.; McIntosh, M. Subtype-selective conopeptides targeted to nicotinic receptors. Channels 2008, 2, 143-152.

5. Azam, L.; McIntosh, J.M. $\alpha$-Conotoxins as pharmacological probes of nicotinic acetylcholine receptors. Acta Pharmacol. Sin. 2009, 30, 771-783.

6. Vincent, A.; Beeson, D.; Lang, B. Molecular targets for autoimmune and genetic disorders of neuromuscular transmission. Eur. J. Biochem. 2000, 267, 6717-6728.

7. O’Neill, M.J.; Murray, T.K.; Lakics, V.; Visanji, N.P.; Duty, S. The role of neuronal nicotinic acetylcholine receptors in acute and chronic neurodegeneration. Curr. Drug Targets CNS Neurol. Disord. 2002, 1, 399-411. 
8. Steinlein, O.K. Nicotinic receptor mutations in human epilepsy. Prog. Brain Res. 2004, 145, $275-285$.

9. Livett, B.G.; Sandall, D.W.; Keays, D.; Down, J.; Gayler, K.R.; Satkunanathan, N.; Khalil, Z. Therapeutic applications of conotoxins that target the neuronal nicotinic acetylcholine receptor. Toxicon 2006, 48, 810-829.

10. Lewis, R.J. Conotoxin venom peptide therapeutics. Adv. Exp. Med. Biol. 2009, 655, 44-48.

11. Kasheverov, I.E.; Utkin, Y.N.; Tsetlin, V.I. Naturally occurring and synthetic peptides acting on nicotinic acetylcholine receptors. Curr. Pharm. Des. 2009, 15, 2430-2452.

12. Dineley, K.T. $\beta$-Amyloid peptide — nicotinic acetylcholine receptor interaction: The two faces of health and disease. Front. Biosci. 2007, 12, 5030-5038.

13. Barrantes, F.J.; Borroni, V.; Vallés, S. Neuronal nicotinic acetylcholine receptor-cholesterol crosstalk in Alzheimer's disease. FEBS Lett. 2010, 584, 1856-1863.

14. Johnson, D.S.; Martinez, J.; Elgoyhen, A.B.; Heinemann, S.F.; McIntosh, J.M. $\alpha$-Conotoxin ImI exhibits subtype-specific nicotinic acetylcholine receptor blockade: Preferential inhibition of homomeric $\alpha 7$ and $\alpha 9$ receptors. Mol. Pharmacol. 1995, 48, 194-199.

15. Pereira, E.F.; Alkondon, M.; McIntosh, J.M.; Albuquerque, E.X. $\alpha$-Conotoxin-ImI: A competitive antagonist at $\alpha$-bungarotoxin-sensitive neuronal nicotinic receptors in hippocampal neurons. J. Pharmacol. Exp. Ther. 1996, 278, 1472-1483.

16. Broxton, N.M.; Down, J.G.; Gehrmann, J.; Alewood, P.F.; Satchell, D.G.; Livett, B.G. $\alpha$-Conotoxin ImI inhibits the $\alpha$-bungarotoxin-resistant nicotinic response in bovine adrenal chromaffin cells. J. Neurochem. 1999, 72, 1656-1662.

17. Ellison, M.; Gao, F.; Wang, H.L.; Sine, S.M.; McIntosh, J.M.; Olivera, B.M. $\alpha$-Conotoxins ImI and ImII target distinct regions of the human $\alpha 7$ nicotinic acetylcholine receptor and distinguish human nicotinic receptor subtypes. Biochemistry 2004, 43, 16019-16026.

18. Hogg, R.C.; Miranda, L.P.; Craik, D.J.; Lewis, R.J.; Alewood, P.F.; Adams, D.J. Single amino acid substitutions in $\alpha$-conotoxin PnIA shift selectivity for subtypes of the mammalian neuronal nicotinic acetylcholine receptor. J. Biol. Chem. 1999, 274, 36559-36564.

19. Luo, S.; Nguyen, T.A.; Cartier, G.E.; Olivera, B.M.; Yoshikami, D.; McIntosh, J.M. Single-residue alteration in $\alpha$-conotoxin PnIA switches its nAChR subtype selectivity. Biochemistry 1999, 38, 14542-14548.

20. Smit, A.B.; Syed, N.I.; Schaap, D.; van Minnen, J.; Klumperman, J.; Kits, K.S.; Lodder, H.; van der Schors, R.C.; van Elk, R.; Sorgedrager, B.; et al. A glia-derived acetylcholine-binding protein that modulates synaptic transmission. Nature 2001, 411, 261-268.

21. Hansen, S.B.; Talley, T.T.; Radic, Z.; Taylor, P. Structural and ligand recognition characteristics of an acetylcholine-binding protein from Aplysia californica. J. Biol. Chem. 2004, 279, 24197-24202.

22. Hansen, S.B.; Sulzenbacher, G.; Huxford, T.; Marchot, P.; Taylor, P.; Bourne, Y. Structures of Aplysia AChBP complexes with nicotinic agonists and antagonists reveal distinctive binding interfaces and conformations. EMBO J. 2005, 24, 3635-3646.

23. Ulens, C.; Hogg, R.C.; Celie, P.H.; Bertrand, D.; Tsetlin, V.; Smit, A.B.; Sixma, T.K. Structural determinants of selective $\alpha$-conotoxin binding to a nicotinic acetylcholine receptor homolog AChBP. Proc. Natl. Acad. Sci. USA 2006, 103, 3615-3620. 
24. Dutertre, S.; Ulens, C.; Büttner, R.; Fish, A.; van Elk, R.; Kendel, Y.; Hopping, G.; Alewood, P.F.; Schroeder, C.; Nicke, A.; et al. AChBP-targeted $\alpha$-conotoxin correlates distinct binding orientations with nAChR subtype selectivity. EMBO J. 2007, 26, 3858-3867.

25. Hu, S.H.; Gehrmann, J.; Guddat, L.W.; Alewood, P.F.; Craik, D.J.; Martin, J.L. The $1.1 \AA$ crystal structure of the neuronal acetylcholine receptor antagonist, $\alpha$-conotoxin PnIA from Conus pennaceus. Structure 1996, 4, 417-423.

26. Hu, S.H.; Gehrmann, J.; Alewood, P.F.; Craik, D.J.; Martin, J.L. Crystal structure at $1.1 \AA$ resolution of $\alpha$-conotoxin PnIB: Comparison with $\alpha$-conotoxins PnIA and GI. Biochemistry 1997, $36,11323-11330$.

27. Kasheverov, I.E.; Zhmak, M.N.; Vulfius, C.A.; Gorbacheva, E.V.; Mordvintsev, D.Y.; Utkin, Y.N.; van Elk, R.; Smit, A.B.; Tsetlin, V.I. $\alpha$-Conotoxin analogs with additional positive charge show increased selectivity towards Torpedo californica and some neuronal subtypes of nicotinic acetylcholine receptors. FEBS J. 2006, 273, 4470-4481.

28. Kasheverov, I.E.; Chiara, D.C.; Zhmak, M.N.; Maslennikov, I.V.; Pashkov, V.S.; Arseniev, A.S.; Utkin, Y.N.; Cohen, J.B.; Tsetlin, V.I. $\alpha$-Conotoxin GI benzoylphenylalanine derivatives: ${ }^{1} \mathrm{H}-\mathrm{NMR}$ structures and photoaffinity labeling of the Torpedo californica nicotinic acetylcholine receptor. FEBS J. 2006, 273, 1373-1388.

29. Mordvintsev, D.Y.; Polyak, Y.L.; Levtsova, O.V.; Tourleigh, Y.V.; Kasheverov, I.E.; Shaitan, K.V.; Utkin, Y.N.; Tsetlin, V.I. A model for short $\alpha$-neurotoxin bound to nicotinic acetylcholine receptor from Torpedo californica: Comparison with long-chain $\alpha$-neurotoxins and a-conotoxins. Comput. Biol. Chem. 2005, 29, 398-411.

30. Bourne, Y.; Talley, T.T.; Hansen, S.B.; Taylor, P.; Marchot, P. Crystal structure of a Cbtx-AChBP complex reveals essential interactions between snake $\alpha$-neurotoxins and nicotinic receptors. EMBO J. 2005, 24, 1512-1522.

31. Unwin, N. Refined structure of the nicotinic acetylcholine receptor at $4 \AA$ resolution. J. Mol. Biol. 2005, 346, 967-989.

32. Ellison, M.; McIntosh, J.M.; Olivera, B.M. $\alpha$-Conotoxins ImI and ImII. Similar $\alpha 7$ nicotinic receptor antagonists act at different sites. J. Biol. Chem. 2003, 278, 757-764.

33. Ellison, M.; Haberlandt, C.; Gomez-Casati, M.E.; Watkins, M.; Elgoyhen, A.B.; McIntosh, J.M.; Olivera, B.M. $\alpha$-RgIA: A novel conotoxin that specifically and potently blocks the $\alpha 9 \alpha 10$ nAChR. Biochemistry 2006, 45, 1511-1517.

34. Ellison, M.; Feng, Z.P.; Park, A.J.; Zhang, X.; Olivera, B.M.; McIntosh, J.M.; Norton, R.S. $\alpha$-RgIA, a novel conotoxin that blocks the $\alpha 9 \alpha 10 \mathrm{nAChR}$ : Structure and identification of key receptor-binding residues. J. Mol. Biol. 2008, 377, 1216-1227.

35. Vincler, M.; Wittenauer, S.; Parker, R.; Ellison, M.; Olivera, B.M.; McIntosh, J.M. Molecular mechanism for analgesia involving specific antagonism of $\alpha 9 \alpha 10$ nicotinic acetylcholine receptors. Proc. Natl. Acad. Sci. USA 2006, 103, 17880-17884.

36. McIntosh, J.M.; Dowell, C.; Watkins, M.; Garrett, J.E.; Yoshikami, D.; Olivera, B.M. $\alpha$-Conotoxin GIC from Conus geographus, a novel peptide antagonist of nicotinic acetylcholine receptors. J. Biol. Chem. 2002, 277, 33610-33615. 
37. McIntosh, J.M.; Plazas, P.V.; Watkins, M.; Gomez-Casati, M.E.; Olivera, B.M.; Elgoyhen, A.B. A novel $\alpha$-conotoxin, PeIA, cloned from Conus pergrandis, discriminates between rat $\alpha 9 \alpha 10$ and a7 nicotinic cholinergic receptors. J. Biol. Chem. 2005, 280, 30107-30112.

38. Talley, T.T.; Olivera, B.M.; Han, K.H.; Christensen, S.B.; Dowell, C.; Tsigelny, I.; Ho, K.Y.; Taylor, P.; McIntosh, J.M. $\alpha$-Conotoxin OmIA is a potent ligand for the acetylcholine-binding protein as well as $\alpha 3 \beta 2$ and $\alpha 7$ nicotinic acetylcholine receptors. J. Biol. Chem. 2006, 281, 24678-24686.

39. Kasheverov, I.; Rozhkova, A.; Zhmak, M.; Utkin, Y.; Ivanov, V.; Tsetlin, V. Photoactivatable $\alpha$-conotoxins reveal contacts with all subunits as well as antagonist-induced rearrangements in the Torpedo californica acetylcholine receptor. Eur. J. Biochem. 2001, 268, 3664-3673.

40. Kasheverov, I.E.; Zhmak, M.N.; Fish, A.; Rucktooa, P.; Khruschov, A.Y.; Osipov, A.V.; Ziganshin, R.H.; D’hoedt, D.; Bertrand, D.; Sixma, T.K.; et al. Interaction of $\alpha$-conotoxin ImII and its analogs with nicotinic receptors and acetylcholine-binding proteins: additional binding sites on Torpedo receptor. J. Neurochem. 2009, 111, 934-944.

41. Srivastava, S.; Hamouda, A.K.; Pandhare, A.; Duddempudi, P.K.; Sanghvi, M.; Cohen, J.B.; Blanton, M.P. [(3)H]Epibatidine photolabels non-equivalent amino acids in the agonist binding site of Torpedo and $\alpha 4 \beta 2$ nicotinic acetylcholine receptors. J. Biol. Chem. 2009, 284, 24939-24947.

42. Brams, M.; Pandya, A.; Kuzmin, D.; van Elk, R.; Krijnen, L.; Yakel, J.L.; Tsetlin, V.; Smit, A.B.; Ulens, C. A structural and mutagenic blueprint for molecular recognition of strychnine and d-tubocurarine by different Cys-loop receptors. PLoS Biol. 2011, 9, 1-12.

43. Sali, A. MODELLER: Program for Comparative Protein Structure Modelling by Satisfaction of Spatial Restraints. Available online: http://salilab.org/modeller (accessed on 10 February 2011).

44. Arnold, K.; Bordoli, L.; Kopp, J.; Schwede, T. The SWISS-MODEL Workspace: A web-based environment for protein structure homology modelling. Bioinformatics 2006, 22, 195-201. Available online: http://swissmodel.expasy.org (accessed on 20 April 2011).

45. The Official UCSF DOCK Website. Available online: http://dock.compbio.ucsf.edu (accessed on 15 May 2011).

46. Ritchie, D. Hex Protein Docking. Available online: http://www.csd.abdn.ac.uk/hex (accessed on 15 May 2011).

47. The Scripps Research Institute. AutoDock. Available online: http://autodock.scripps.edu (accessed on 29 April 2011).

48. Dominguez, C.; Boelens, R.; Bonvin, A.M.J.J. HADDOCK: a protein-protein docking approach based on biochemical and/or biophysical information. J. Am. Chem. Soc. 2003, 125, 1731-1737. Available online: http://www.nmr.chem.uu.nl/haddock (accessed on 29 April 2011).

49. Kasheverov, I.; Zhmak, M.; Chivilyov, E.; Saez-Brionez, P.; Utkin, Y.; Hucho, F.; Tsetlin, V. Benzophenone-type photoactivatable derivatives of $\alpha$-neurotoxins and $\alpha$-conotoxins in studies on Torpedo nicotinic acetylcholine receptor. J. Recept. Signal Transduct. Res. 1999, 19, 559-571.

Samples Availability: Available from the authors.

(C) 2011 by the authors; licensee MDPI, Basel, Switzerland. This article is an open access article distributed under the terms and conditions of the Creative Commons Attribution license (http://creativecommons.org/licenses/by/3.0/). 